\title{
PALABRAS DEL RECTOR
}

$\mathrm{E}$

1 tiempo es un enigma que solo Dios puede descifrar; pasa más rápido de lo que uno desea y más lentamente de lo que uno teme. Como son los hombres son los tiempos. La utilidad del tiempo constituye la perfección humana, y su desperdicio, el estancamiento.

Es el tiempo el que nos conduce en esta ocasión a la presentación de un nuevo número de la revista Lex, pero también, coincidentemente, a la celebración del decimocuarto aniversario de creación y funcionamiento de la Facultad de Derecho y Ciencia Política de nuestra Universidad, cuya evocación trae inevitablemente halagüeñas reminiscencia.

En relación con esta nueva edición de Lex, que ya se ha constituido en el alimento jurídico semestral de estudiantes y profesionales de la especialidad, merced a su valioso aporte de pensamientos y concepciones teóricas sobre los principios fundamentales y filosóficos del Derecho, debemos expresar nuestra enorme satisfacción por su posicionamiento a nivel nacional e internacional como publicación acreditada gracias a su inclusión en el catálogo oficial de LATINDEX y a la difusión masiva de sus contenidos a través de su versión electrónica en la página web de la Universidad Alas Peruanas.

La Facultad de Derecho de nuestra Universidad se crea cuando se extinguía el siglo XX, caracterizado por el desarrollo vertiginoso de la ciencia y la tecnología, lo que trajo un cambio en todo orden de cosas y la consecuente aparición de nuevas leyes y, con ellas, la dación de renovados códigos, adecuados a la realidad nacional.

Catorce años después del inicio del funcionamiento de la Facultad de Derecho, se puede afirmar que las promociones de abogados egresados constituyen un grupo de profesionales solventes, con nuevas proyecciones y adaptados al devenir casuístico de estos tiempos. Así, la nota característica de esta nueva Facultad ha sido el crecimiento, su ascendencia en la juventud y el espíritu de innovación que mantiene hasta el presente.

Por su parte, la presencia de Lex resulta ya un fanal reconocido. En sus páginas se siguen difundiendo no solo las opiniones de profesores y de graduados de la Facultad, sino también de maestros peruanos y extranjeros empeñados en el análisis especulativo de cuanto acontece y afecta al desarrollo de la sociedad, a fin de abordar la problemática que la aqueja y lograr la solución de la misma. 
La Facultad de Derecho de la UAP y la revista Lex se han convertido en un binomio indestructible que ha venido y viene ilustrando la teoría y la práctica de la ciencia jurídica, llegando a erigirse en una atalaya desde la que se observa y enaltece la filosofía jurídica del país.

En un país como el nuestro, donde ciertos valores culturales se van olvidando, para imponer axiologías extranjeras, resulta elocuente que se editen voceros que clarifiquen y orienten adecuadamente a la juventud y a la sociedad.

El Perú cuenta con un legado histórico jurídico brillante del que se pueden extraer enseñanzas paradigmáticas, y para esa tarea se hallarán siempre prestas nuestra Facultad y, por supuesto, la revista Lex, aportando ideas y mensajes que contribuyan al rescate y valoración del quehacer jurídico.

Dr. Fidel Ramírez Prado, Ph.D. 